\title{
Show and Tell Technique in Teaching Speaking Skills at SMAN 2 Palopo
}

\author{
Anisah Fitriani \\ 1,2.3Institut Agama Islam Negeri Palopo (IAIN Palopo), Palopo, Indonesia \\ anis.anisahfitriani.bakri@gmail.com
}

\begin{abstract}
This research focused on using Show and Tell techniques to develop students' speaking skills at Eleventh class of SMA Negeri 2 Palopo. The researcher used pre-experimental method. The population of this research is 157 students of XI class. The research sample is chosen purposively and got the XI IPA 1 consisting of 35 students. In collecting the data, the researcher used speaking observations, divided into pre-survey and post-survey. After giving pre-survey and post-survey, this research provides pre-survey and postsurvey to students. Data were analyzed using SPSS program version 20 . The results of the study indicated that the use of Show and Tell Technique is effective for improving students' speaking skills. It can be seen calculation results that the scores of students in the control class. Based on the analysis of the data it can be concluded that the teaching skills of speaking using Show and Tell Techniques at Eleventh class of SMA Negeri 2 Palopo. The implementation of this research for those who are interested in conducting research on problem statements, it is recommended to apply it to students who have basic speaking language skills and researchers hope that the results of this study can be beneficial to readers.
\end{abstract}

Keywords: English Language Teaching, Show and Tell technique, Teaching Speaking Skills

\section{INTRODUCTION}

Speaking is one of the communication main elements. In EFL, instruction it was requires that particular attitude and distraction. Interaction effectively comes from analysis carefully of this place along adequately language usage and promotional some interest it that will with gradual help students speak English with fluent and correctly (Richard: 2002). Kang Sumin said that speaking language is particularly difficult for students to use language correctly in social interactions. To learn a second language or foreign languages difficult as we learned our native language as a child (Clasrk: 1997).

In addition to factors in students, teacher teaching methods and styles also greatly affect students' speaking abilities. The lack of teacher knowledge about learning methods to stimulate students' speaking abilities is also one of the causes (Irvy, 2020). Teachers usually only use the lecture method (teacher centered) and rarely provide opportunities for students to talk about their experiences or express their opinions in front of the class. Learning methods that only use one-way methods namely the teacher explains or lectures make students become very minimal. This makes the development of students' speaking abilities less optimal so that students are less motivated and stimulated by their speaking abilities and vocabulary addition. With the importance of the ability to speak, it is necessary to have a stimulus given both from parents and teachers and the 
environment to develop students' speaking abilities. As an educator should be creative and innovative in providing learning methods and media to students to stimulate and motivate students' speaking abilities (Anwar et al., 2020). Motivation or stimulus given to students should be given outside or the environment and from within students themselves.

It is the problem faced by students was very difficult in speaking and not mastered speaking, not confident especially in asking questions or answer a question given by the teacher, the student was less motivated and who has not mastered speaking because of lack of vocabulary. And the use of English was very difficult to master by students because in addition to using the English language is also able to know the purpose of the sentence. So that, in the learning process students was not creative in talking and making sentences in daily activity.

Numbers of study have been conducted related to the Show and Tell Metohod, including Wulandari (2014) doing a research about improving the children confidence through Show and Tell Method found that students' confidence in the A PAUD Miana V group increased after adopting a method of Show and Tell technique. It can make students more confidents as learning English and also more courageous and more organized children to tell stories to their teachers or friend, they can do their own duty. On the other hand, Nurvitasyari (2017), studying about the use of show and tell method in teaching vocabulary at SMP Negeri 4 Galesong Selatan Kabupaten Takalar" found that the use of show and tell method can increase students' vocabulary mastery. The method contributes to student control in the vocabulary. It can increase students' understanding of words. This method can enhance student vocabulary control. This is evidenced with value of t-test 14.12 greater than the value of t-table 2.042.

In 2015, Eka Trislijayanti also had research about the use of Show and Tell Method in teaching Bahasa Indonesia SMP Negeri 1 Seririt. She concluded that: a) of students' speaking skills get increased applying Show and Tell methods; b) The learning steps to speak properly by applying performance methods and informing with media pictures are divided into three stages, namely introduction, core activity, and closure(Iksan, 2017). In the preliminary stage, the teacher gives apperception related to the material being taught. At the core activity stage, the teacher assigns students to describe pictures. In the closing stages, the teacher reflects on and evaluates the activities that have already taken place and provides reinforcement to students because they are already active when learning takes place; c) Students gave very positive responses to the application of the Show and Tell method with picture media in speaking learning. The studies above show positive findings about the use of the method in language teaching and learning. While, based on the fact found on preliminary investigation, generally, students' ability at SMA Negeri 2 Palopo speaking skill were still low. Therefore, the writer was interested in conducting a research to find out whether Show and Tell Technique improves students' speaking skill at Eleventh class of Senior High School Negeri 2 Palopo.

\section{METHODS}

\section{Research Method and Design}

In this research, author employed before-experimental system. This system was applied to know effectiveness of Show and Tell technique in instruction saying ability at Eleventh class of SMA Negeri 2 Palopo. Formula of research design is illustrated below: 


$\begin{array}{lcc}\text { Pre-survey } & \text { Treatment } & \text { Post-survey } \\ \text { O1 } & \mathrm{X} & \mathrm{O} 2\end{array}$

Where:

01 : Pre-survey

$\mathrm{X}$ : Treatment

02 : Post-survey (Sugiyono: 2008)

\section{Location and Time of Research}

\section{Location}

Researcher delivered editing at Eleventh of SMA Negeri 2 Palopo.

2. Time of the Research

The researcher conducted research at Eleventh grade of SMA Negeri 2 Palopo start from on February 20 th to March $11^{\text {th }}, 2020$.

\section{Variable}

The variable of this research, the researcher was consisting of two variables socalled self-sufficient variable and depend variable:

1. Show and Tell technique as independent variable

Show and Tell technique was a technique that plays about describing thing.

2. Students' speaking skill as dependent variable

The ability of students in English is different, especially, in vocabulary and listening. If the students have not speaking, the students will be difficult to understand to learn about English. To improve students speaking skill can used the Show and Tell technique to teach students and to improve their speaking.

\section{Population and Sample}

\section{Population}

Population of this editing is entire Eleventh class of SMA Negeri 2 Palopo in 2019/2020 academic year that consisted of 157 students, there were five classes, class XI IPA1 consisted 35 students, class XI IPA2 consisted 34 students, XI IPA3 consisted 26 students, XI IPS1 consisted 32 students and XI IPS2 consisted 30 students.

\section{Sample}

Author applied which was used sampling technique. In this case, author will select room XI IPA1 as sample. The students consisted 35 students. There were boys and girls. They were around seventeen-years old. They had the same level of proficiency, because they are taught by the same teacher.

\section{Instrument of the Research}

In this research, author applied show and tell technique. The test consisted of presurvey and post-survey. The show and tell technique of survey was describing noun or thing which consisted of 8 parts of speech, 3 tenses, and descriptive text. The researcher used show and tell method which has $5 \mathrm{E}$ in the learning process that is having an engagement, exploration, explanation, elaboration, and then evaluation. 


\section{Procedure of Collecting Data}

The procedure of collecting data held with the sequence as follows:

\section{Giving Pre-survey}

The Pre-survey applied to find out the students' ability of speaking that uses Show and Tell technique. A pre-survey was used to know the previous mastery of students in mastering speaking skills before giving treatment. The Show and Tell technique will be given the students to describe about things every meeting. For the things that had described, the students made a sentence by linking the things.

\section{Giving Treatment}

The researcher conducted treatments done four meetings. Processes are as follows:

a. Second meeting on February $20^{\text {th }}, 2020$. The researcher had given the treatment in class the material gave were what is Show and Tell technique? And what is Noun? Example words of Noun such Things. In treatment, author described delineation about Noun to learners with applying Images. Then, research would provide 10 vocabulary words for each meeting.

b. The Third meeting on February $26^{\text {th }}, 2020$. The material gave parts of Speech. The researcher asked students to mention what is part of speech. Then, the researcher gives an understanding of the part of speech along with an example. The parts of speech are noun, pronoun, verb, adjective, adverb, preposition, conjunction, and interjection. Then, the researcher will provide 10 vocabulary words.

c. The Forth meeting on March 04th, 2020 . The material gave Tenses. The researcher asked students to mention what are tenses. Then, the researcher gave an understanding of the tenses along with an example. The tenses were simple past tense, simple present tense, and simple future tense. Then, the researcher would provide 10 vocabulary words.

d. The Fifth meeting on March 11 1 th 2020 . The material gave what is descriptive text? Example about descriptive text by using pictures and show and tell technique.

\section{Giving Post-survey}

Since allocating treatments to four meetings, author allocated the post-test. In post-survey, researcher gave the test the same test as in the pre-survey to the students. This survey was to know whether the students. This exam was to know whether students have a different result after giving treatment or not.

\section{Technique of Analyzing Data}

The researcher was use quantitative analysis with incoming point and standard deviation of data and t-test paired sample with used SPSS 20.0. The author surveyed it with used assessment score accuracy, fluency, and comprehension from Heaton (1990).

To analyze learner's speaking test, there would be some identity applied by the author for learner' point by scoring the students speaking test result. Those assessment criteria as follows:

Table 1. Accuracy criteria

\begin{tabular}{cl}
\hline Rating & \multicolumn{1}{c}{ Accuracy } \\
\hline 6 & $\begin{array}{l}\text { Articulation is only very with slight governed with mother tongue. Two or three } \\
\text { small grammatical or lexical wrongs. }\end{array}$ \\
\hline
\end{tabular}




\begin{tabular}{cl}
\hline 5 & $\begin{array}{l}\text { Articulation is with slight governed with mother tongue. A few small grammatical } \\
\text { and lexical wrongs but most facial experiences were true. } \\
\text { Articulation was still with moderate governed with mother tongue but no solemn } \\
\text { phonological wrongs. Handful grammatical and lexical wrongs but only one or } \\
\text { two major wrongs raising disorder. }\end{array}$ \\
3 & $\begin{array}{l}\text { Articulation is governed with mother tongue but only handful solemn } \\
\text { phonological and lexical wrongs, several of which raise disorder. }\end{array}$ \\
2 & $\begin{array}{l}\text { Articulation with solemn governed with mother by wrongs raising a snap in } \\
\text { communications. Many elementary and grammatical wrongs. }\end{array}$ \\
1 & $\begin{array}{l}\text { Solemn articulation wrongs as good as many elementary grammatical and lexical } \\
\text { wrongs. No proof of telling dominated several of language abilities and places } \\
\text { does in purpose. }\end{array}$
\end{tabular}

Table 2. Fluency criteria

\begin{tabular}{cl}
\hline Rating & \multicolumn{1}{c}{ Fluency } \\
\hline 6 & $\begin{array}{l}\text { Says without overly amazing and venture by fair extensive way of idiom. Quests } \\
\text { for words with occasional but not only one or two no natural halt. }\end{array}$ \\
5 & $\begin{array}{l}\text { Has to create an attempt at periods to seek for words. Soft dispatch on all and } \\
\text { only handful no natural paused. }\end{array}$ \\
4 & $\begin{array}{l}\text { He is created an attempt and seeks for paragraphs, they are not overly many no } \\
\text { natural paused. With fair smooth delivery with most. With occasional } \\
\text { incomplete but successful in bringing public purpose. Just range distance. }\end{array}$ \\
3 & $\begin{array}{l}\text { Is creates an attempt for many of periods. Often is seeks for desirable purpose. } \\
\text { Better hesitate dispatch and incomplete. Distance of idiom often finite. } \\
\text { Lengthy rest while he/she author for desirable purpose. With frequent } \\
\text { incomplete and hesitate dispatch. Almost give up creating attempts at period. } \\
\text { Finite distance of idiom. }\end{array}$ \\
& $\begin{array}{l}\text { Full of lengthy and no natural rest. Very hesitate and incomplete dispatch. At } \\
\text { periods gives up creating attempt. Very finite distance of idiom. }\end{array}$ \\
\hline
\end{tabular}

Table 3. The Comprehensibility criteria

\begin{tabular}{cl}
\hline Rating & \multicolumn{1}{c}{ Comprehensibility } \\
\hline 6 & $\begin{array}{l}\text { Simple of hearer comprehend speaker's intention and public purpose. Very } \\
\text { handful interferences or clarification that is need. }\end{array}$ \\
5 & $\begin{array}{l}\text { Speaker's purpose and public purpose are with fair pure. Handful interference } \\
\text { with hearer for towards for illustration was necessity. }\end{array}$ \\
& $\begin{array}{l}\text { Most of what sayer speaks in simple to obey. His/her mention is always } \\
\text { understood but some distractions were necessity to assist him/her to speak } \\
\text { letter to asked explanation. }\end{array}$ \\
3 & $\begin{array}{l}\text { Hearer can to comprehend a lot of what is spoken, but he/she must with } \\
\text { constant asked explanation. Cannot comprehend many of speaker's more } \\
\text { involved or longer sentences. } \\
\text { Only little handful (generally low sentence and phrase) can be realized and then } \\
\text { with considerable attempt with someone who is applyed to hearing to sayer. }\end{array}$ \\
2
\end{tabular}




\begin{tabular}{cl}
\hline Rating & \multicolumn{1}{c}{ Comprehensibility } \\
\hline 1 & $\begin{array}{l}\text { With hard anything of what is spoken can be realized. Even when hearers create } \\
\text { a great attempt suppress, sayers is incapable to clarity anything he/she seems } \\
\text { to has spoken. }\end{array}$ \\
\hline
\end{tabular}

(Heaton: 1990)

Result of students' speaking tests will be determined by classification students. It could be seen in the table below. The score of three tables above was converted into a score in the next table by using formula below:

A student's score $=\frac{\text { The gain score }}{\text { The maximun score }} \times 100$

(Brown: 2004)

Beside technique for pointing through six balance above, author also makes evaluation classification to survey student's saying aptitude. Obeying was evaluation balance classification:

Table 4. Evaluation balance classification

\begin{tabular}{lllll}
\hline \multicolumn{1}{c}{ Classification } & Scale & & Evaluation \\
\hline Excellent & $86-100$ & 6 & \\
Very good & $71-85$ & 5 & \\
Good & $56-70$ & 4 & \\
Fairly good & $41-55$ & 3 & \\
Poor & $26-40$ & 2 & \\
Very poor & $1-25$ & 1 & \\
\hline
\end{tabular}

Daryanto: 2007)

Data collection analyzed with applying quantitative with applying Statistical Procedure and Service solution (SPSS) ver. 20 for windows. SPSS 20 is computer software/Program for stepping, evaluating or analysis data of statistics.

\section{RESULTS}

Findings of research showed result of data that have been analyzed with statistical. It comprised students' score of pre-test and post-test.

\section{Students' score of Pre-survey}

Table 5. Point of Students' Pre-test Result

\begin{tabular}{ccccc}
\hline \multirow{2}{*}{ Students } & \multicolumn{3}{c}{ Aspects of Speaking Skill } & \multirow{2}{*}{ Mean } \\
\cline { 2 - 4 } & Accuracy & Fluency & Comprehensibility & \\
\hline S1 & 2 & 1 & 2 & 5 \\
S2 & 2 & 2 & 1 & 5 \\
S3 & 1 & 2 & 2 & 5 \\
S4 & 3 & 3 & 3 & 9 \\
S5 & 1 & 2 & 1 & 4 \\
S6 & 2 & 2 & 1 & 5 \\
S7 & 3 & 3 & 3 & 9 \\
S8 & 1 & 1 & 1 & 3 \\
S9 & 3 & 3 & 3 & 9 \\
\hline
\end{tabular}




\begin{tabular}{ccccc}
\hline \multirow{2}{*}{ Students } & \multicolumn{3}{c}{ Aspects of Speaking Skill } & \multirow{2}{*}{ Mean } \\
\cline { 2 - 4 } S10 & Accuracy & Fluency & Comprehensibility & \\
S11 & 2 & 1 & 1 & 4 \\
S12 & 1 & 2 & 2 & 5 \\
S13 & 2 & 2 & 1 & 5 \\
S14 & 1 & 2 & 1 & 4 \\
S15 & 2 & 2 & 2 & 5 \\
S16 & 3 & 2 & 2 & 7 \\
S17 & 2 & 1 & 1 & 5 \\
S18 & 1 & 1 & 2 & 3 \\
S19 & 2 & 1 & 3 & 5 \\
S20 & 2 & 3 & 3 & 8 \\
S21 & 3 & 3 & 3 & 9 \\
S22 & 3 & 3 & 1 & 9 \\
S23 & 2 & 2 & 2 & 5 \\
S24 & 2 & 2 & 2 & 6 \\
S25 & 2 & 2 & 2 & 6 \\
S26 & 2 & 2 & 2 & 5 \\
S27 & 2 & 1 & 1 & 5 \\
S28 & 2 & 2 & 3 & 9 \\
S29 & 3 & 3 & 1 & 5 \\
S30 & 2 & 2 & 2 & 5 \\
S31 & 2 & 1 & 1 & 6 \\
S32 & 3 & 2 & 1 & 5 \\
S33 & 2 & 2 & 2 & 6 \\
S34 & 2 & 2 & 2 & 5 \\
S35 & 2 & 1 & 3 & 9 \\
\hline Speannnnn & 3 & 2 & 5 \\
\end{tabular}

Speaking ability composed of three aspects; namely accuracy, fluency, and comprehensibility. Author would allocate and pack intend point of learners saying ability one with one. All of those would describe with attending lists:

Table 6. Rate percentage point of students' accuracy in pre-test result

\begin{tabular}{|c|c|c|c|}
\hline Classification & Score & Frequency & Percentage \\
\hline Excellent & 6 & - & - \\
\hline Very good & 5 & - & - \\
\hline Good & 4 & - & - \\
\hline Fairly good & 3 & 8 & $23 \%$ \\
\hline Poor & 2 & 17 & $51 \%$ \\
\hline Very poor & 1 & 10 & $26 \%$ \\
\hline \multicolumn{2}{|c|}{ Total } & 35 & $100 \%$ \\
\hline
\end{tabular}

Table 6 shows that, there were 8 students (23\%) got fairly good score. There were 17 students (51\%) who got poor score. There were 10 learners (26\%) who got very poor score.

Table 7. Rate Percentage Point of Students' Accuracy in Pre-test result 


\begin{tabular}{cccccccc}
\hline & \multicolumn{7}{c}{ Descriptive Statistics } \\
\hline & $\mathrm{N}$ & Range & Minimum & Maximum & Sum & \multicolumn{2}{c}{ Mean } \\
\cline { 2 - 8 } & Statistic & Statistic & Statistic & Statistic & Statistic & Statistic & Std. Error \\
\cline { 2 - 8 } & 35 & 2 & 1 & 3 & 69 & 1.97 & .119 \\
$\begin{array}{c}\text { Accuracy pre- } \\
\text { survey } \\
\begin{array}{c}\text { Valid N (list- } \\
\text { wise) }\end{array}\end{array}$ & 35 & & & & & & \\
\hline
\end{tabular}

Table 7 explains intend point of accuracy got with learners in pre-test. It can be regarded with clear from these lists intend point is 1.97 and it represents these saying aptitude of the students.

Table 8. Rate Percentage Point of Learners' Fluency in Pre-test result

\begin{tabular}{|c|c|c|c|}
\hline Classification & Score & Frequency & Percentage \\
\hline Excellent & 6 & - & - \\
\hline Very good & 5 & - & - \\
\hline Good & 4 & - & - \\
\hline Fairly good & 3 & 11 & $29 \%$ \\
\hline Poor & 2 & 19 & $54 \%$ \\
\hline Very poor & 1 & 5 & $17 \%$ \\
\hline \multicolumn{2}{|c|}{ Total } & 35 & $100 \%$ \\
\hline
\end{tabular}

Table 8 shows that there were 11 students (29\%) got fairly good score. There were 19 learners (54\%) who got poor score. There were 5 learners (17\%) who got very poor score.

Table 9. Mean Point of Students' Fluency Pre-test result

\begin{tabular}{cccccccc}
\hline & \multicolumn{7}{c}{ Descriptive Statistics } \\
\hline & Statistic & Statistic & Statistic & Statistic & Statistic & Statistic & Std. Error \\
\hline $\begin{array}{c}\text { Fluency pre- } \\
\text { survey }\end{array}$ & 35 & 2 & 1 & 3 & 73 & 2.09 & .111 \\
$\begin{array}{c}\text { Valid N (list- } \\
\text { wise) }\end{array}$ & 35 & & & & & & \\
\hline
\end{tabular}

In table 9, it can be seen that highest point of learners is 3 and the lowest point was 1 . It also indicates that mean point of learners' accuracy 1.97 and standard deviation error was 111.

Table 10. Rate Percentage Point of Learners' Comprehensibility in Pre-test Result

\begin{tabular}{cccc}
\hline Classification & Score & Frequency & Percentage \\
\hline Excellent & 6 & - & - \\
Very good & 5 & - & - \\
Good & 4 & - & - \\
Fairly good & 3 & 8 & $23 \%$ \\
\hline
\end{tabular}




\begin{tabular}{ccccc}
\hline Poor & & 2 & 13 & $37 \%$ \\
Very poor & 1 & 14 & $40 \%$ \\
& Total & & 35 & $100 \%$ \\
\hline
\end{tabular}

Table 10 shows that, there were 8 students (23\%) got fairly good score. There were 13 learners (37\%) who got poor score. There were 14 learners (40\%) who got very poor score.

Table 11. Mean Point of Learners' Comprehensibility Pre-survey result

\begin{tabular}{lrrrrrrrr}
\hline \multicolumn{7}{c}{ Descriptive Statistics } \\
\hline & $\mathrm{N}$ & Range & Minimum & Maximum & Sum & \multicolumn{2}{c}{ Mean } \\
\cline { 2 - 9 } & Statistic & Statistic & Statistic & Statistic & Statistic & Statistic & Std. Error \\
\hline $\begin{array}{l}\text { Comprehensibility } \\
\text { pre-survey }\end{array}$ & 35 & 2 & 1 & 3 & 64 & 1.83 & .133 \\
Valid N (list-wise) & 35 & & & & & & & \\
\hline
\end{tabular}

In table 11, it can be seen that highest point of learners was 3 and lowest 1 . It also indicates that mean point of learners' comprehensibility in pre-survey was 1.83 and standard deviation error is 133.

\section{Students' score of Post-survey}

After knowing learners' point in pre-test, author to take them treatment with applying Show and Tell technique. The result of learners' point in post-test gave in attending list with dividing them into three aspect, they were accuracy, fluency, and comprehensibility.

Table 12. Learners' Score

\begin{tabular}{ccccc}
\hline \multirow{2}{*}{ Students } & \multicolumn{3}{c}{ The Aspects of Speaking Skill } & Mean \\
\cline { 2 - 4 } & Accuracy & Fluency & Comprehensibility & \\
\hline S1 & 4 & 2 & 3 & 9 \\
S2 & 3 & 3 & 2 & 8 \\
S3 & 2 & 3 & 3 & 8 \\
S4 & 5 & 5 & 6 & 16 \\
S5 & 2 & 2 & 2 & 6 \\
S6 & 3 & 3 & 2 & 8 \\
S7 & 6 & 5 & 4 & 15 \\
S8 & 4 & 3 & 2 & 9 \\
S9 & 6 & 5 & 6 & 17 \\
S10 & 3 & 2 & 4 & 9 \\
S11 & 5 & 4 & 5 & 14 \\
S12 & 5 & 3 & 4 & 12 \\
\hline
\end{tabular}




\begin{tabular}{|c|c|c|c|c|}
\hline S13 & 3 & 2 & 3 & 8 \\
\hline S14 & 4 & 3 & 2 & 9 \\
\hline S15 & 5 & 5 & 4 & 14 \\
\hline S16 & 3 & 4 & 2 & 9 \\
\hline S17 & 3 & 3 & 2 & 8 \\
\hline S18 & 3 & 3 & 4 & 10 \\
\hline S19 & 3 & 5 & 5 & 13 \\
\hline S20 & 5 & 5 & 4 & 14 \\
\hline S21 & 6 & 5 & 4 & 15 \\
\hline S22 & 5 & 4 & 3 & 12 \\
\hline S23 & 4 & 4 & 4 & 12 \\
\hline S24 & 4 & 4 & 5 & 13 \\
\hline S25 & 5 & 3 & 4 & 12 \\
\hline S26 & 4 & 4 & 3 & 11 \\
\hline S27 & 4 & 3 & 4 & 11 \\
\hline S28 & 5 & 5 & 5 & 15 \\
\hline S29 & 4 & 3 & 2 & 9 \\
\hline S30 & 4 & 4 & 3 & 11 \\
\hline S31 & 5 & 4 & 4 & 13 \\
\hline S32 & 5 & 4 & 5 & 14 \\
\hline S33 & 5 & 3 & 4 & 12 \\
\hline S34 & 3 & 3 & 2 & 8 \\
\hline S35 & 6 & 5 & 5 & 16 \\
\hline
\end{tabular}

In other side, author had classified based on English saying assessments that composed of accuracy, fluency, and comprehensibility and it is presented through list distribution frequency and percentage.

Table 13. rate percentage point of learners'

\begin{tabular}{cccc}
\hline Classification & Score & Frequency & Percentage \\
\hline Excellent & 6 & - & - \\
Very good & 5 & 9 & $26 \%$ \\
Good & 4 & 9 & $26 \%$ \\
Fairly good & 3 & 13 & $37 \%$ \\
Poor & 2 & 4 & $11 \%$ \\
\hline
\end{tabular}


$100 \%$

Table 13 shows that, there were 9 learners (26\%) got very good score. There were 9 learners (26\%) who got good score. There were 13 learners (37\%) who got fairly good score. There were 4 learners (11\%) who got poor score.

Table 14. Mean Point of Learners' Accuracy

\begin{tabular}{ccccccc}
\hline \multicolumn{7}{c}{ Descriptive Statistics } \\
\hline & Statistic & Minimum & Maximum & Sum & \multicolumn{2}{c}{ Mean } \\
\hline $\begin{array}{c}\text { Accuracy post- } \\
\text { survey } \\
\begin{array}{c}\text { Valid N (list- } \\
\text { wise) }\end{array}\end{array}$ & 35 & 2 & Statistic & Statistic & Statistic & Std. Error \\
\hline
\end{tabular}

In table 14, it can be seen that highest score of learners' accuracy were 5 and lowest score were 2. It also represents that mean point of learners' accuracy in post-survey were 3.66 and standard error .169.

Table 15. the rate percentage score of students' fluency

\begin{tabular}{|c|c|c|c|}
\hline Classification & Score & Frequency & Percentage \\
\hline Excellent & 6 & 4 & $11 \%$ \\
\hline Very good & 5 & 11 & $31 \%$ \\
\hline Good & 4 & 9 & $26 \%$ \\
\hline Fairly good & 3 & 9 & $26 \%$ \\
\hline Poor & 2 & 2 & $6 \%$ \\
\hline Very poor & 1 & - & - \\
\hline \multicolumn{2}{|c|}{ Total } & 35 & $100 \%$ \\
\hline
\end{tabular}

Table 15 shows that, there were 4 learners (11\%) got excellent point. There were 11 learners $(31 \%)$ who got very good point. There were 9 learners $(26 \%)$ who got good point. There were 9 learners (26\%) who got fairly good score. There were 2 students $(6 \%)$ who got poor score.

Table 16. Mean Point of Learners' Fluency

\begin{tabular}{ccccccc}
\hline & \multicolumn{4}{c}{ Descriptive Statistics } & \multicolumn{2}{c}{ Mean } \\
\cline { 2 - 7 } & Statistic & Statistic & Statistic & Statistic & Statistic & Std. Error \\
\hline $\begin{array}{c}\text { Fluency post- } \\
\text { survey } \\
\begin{array}{c}\text { Valid N (list- } \\
\text { wise) }\end{array}\end{array}$ & 35 & 2 & 6 & 146 & 4.17 & .190 \\
\hline
\end{tabular}

In table 16, it can be seen that highest point of learners were 6 and lowest point were 2. It also indicates that mean point of learners' fluency in post-survey is 4.17 and standard error 190 . 
Table 17. Rate percentage point of learners' comprehensibility

\begin{tabular}{|c|c|c|c|}
\hline Classification & Score & Frequency & Percentage \\
\hline Excellent & 6 & 2 & $6 \%$ \\
\hline Very good & 5 & 6 & $17 \%$ \\
\hline Good & 4 & 12 & $34 \%$ \\
\hline Fairly good & 3 & 6 & $17 \%$ \\
\hline Poor & 2 & 9 & $26 \%$ \\
\hline Very poor & 1 & - & - \\
\hline \multicolumn{2}{|c|}{ Total } & 35 & $100 \%$ \\
\hline
\end{tabular}

Table 17 shows that, there were 2 students (6\%) got excellent score. There were 6 learners $(17 \%)$ who got very good point. There were 12 learners $(34 \%)$ who got good point. There were 6 learners $(17 \%)$ who got fairly good point. There were 9 learners $(26 \%)$ who got poor score.

Table 18. Mean Point of Learners' Comprehensibility

\begin{tabular}{|c|c|c|c|c|c|c|}
\hline \multicolumn{7}{|c|}{ Descriptive Statistics } \\
\hline & $\mathrm{N}$ & Minimum & Maximum & Sum & & \\
\hline & Statistic & Statistic & Statistic & Statistic & Statistic & Std. Error \\
\hline $\begin{array}{c}\text { Comprehensibility } \\
\text { post-survey }\end{array}$ & 35 & 2 & 6 & 126 & 3.60 & .206 \\
\hline Valid N (list-wise) & 35 & & & & & \\
\hline
\end{tabular}

In table 18, it can be seen that highest point of learners' were 6 and lowest point were 2. It also indicates that mean point of learners' comprehensibility in post-survey is 3.60 and standard error 206.

The Mean Score of Students' Pre-survey and Post-survey result.

Table 19. Mean Point of Learners' Pre-test result

\begin{tabular}{ccccccc}
\hline \multicolumn{7}{c}{ Descriptive Statistics } \\
\hline & $\mathrm{N}$ & Minimum & Maximum & Sum & Mean & Std. Deviation \\
\hline $\begin{array}{c}\text { Pre-survey } \\
\begin{array}{c}\text { Valid N (list- } \\
\text { wise) }\end{array}\end{array}$ & 35 & 3 & 9 & 206 & 5.89 & 1.827 \\
\hline
\end{tabular}

Table 19 shows that highest point of learners in pre-survey was 9 and the lowest score were 3. Besides, it also indicated that mean point of learners in pre-test was 5.89 and standard deviation was 1.827 .

Table 20. Mean Point of Learners' Post-survey result

\begin{tabular}{ccccccc}
\hline \multicolumn{7}{c}{ Descriptive Statistics } \\
\hline & N & Minimum & Maximum & Sum & Mean & Std. Deviation \\
\hline Post-survey & 35 & 6 & 17 & 400 & 11.43 & 2.893 \\
Valid N (list-wise) & 35 & & & & & \\
\hline
\end{tabular}


Table 20 shows that highest point of learners in post-survey was 17 and lowest points are 6 . Besides, it also indicated that mean point of learners in post-survey was 11.43 and standard deviation is 2.893 .

\section{The calculation of t-test Pre-survey and Post-survey result}

Table 21. Students' Result of t-test from Pre-survey and Post-survey result

\begin{tabular}{lrrrr}
\hline \multicolumn{5}{c}{ One-Sample Statistics } \\
\hline & $\mathrm{N}$ & \multicolumn{4}{c}{ Mean } & Std. Deviation & Std. Error Mean \\
\hline Pre-survey & 35 & 5.89 & 1.827 & .309 \\
Post-survey & 35 & 11.43 & 2.893 & .489 \\
\hline
\end{tabular}

Table 21 shows that survey mean of pre-test is 5.89 and survey mean of post-test is 11.43 , the $\mathrm{N}$ (number of the case) was 35 students. The standard deviation for pre-survey was 1.827 and the standard deviation for post-survey was 2.893. The standard error mean for pre-survey was .309 and standard error mean for post-test is .489. The description of t-test was described by the following table.

Table 22. probability Value of T-Test of Pre-survey and Post-survey

\begin{tabular}{|c|c|c|c|c|c|c|c|c|c|}
\hline \multicolumn{10}{|c|}{ Paired Samples Test } \\
\hline & & \multicolumn{5}{|c|}{ Paired Differences } & \multirow{3}{*}{$\mathrm{t}$} & \multirow{3}{*}{$\mathrm{df}$} & \multirow{3}{*}{$\begin{array}{l}\text { Sig. (2- } \\
\text { tailed) }\end{array}$} \\
\hline & & \multirow[t]{2}{*}{ Mean } & \multirow[t]{2}{*}{$\begin{array}{c}\text { Std. } \\
\text { Deviation }\end{array}$} & \multirow{2}{*}{$\begin{array}{l}\text { Std. } \\
\text { Error } \\
\text { Mean }\end{array}$} & \multicolumn{2}{|c|}{$\begin{array}{l}95 \% \text { Confidence } \\
\text { Interval of the } \\
\text { Difference }\end{array}$} & & & \\
\hline & & & & & Lower & Upper & & & \\
\hline $\begin{array}{c}\text { Pair } \\
1\end{array}$ & $\begin{array}{l}\text { Pre-survey - } \\
\text { post-survey }\end{array}$ & $\begin{array}{c}- \\
5.543\end{array}$ & 1.704 & .288 & -6.128 & -4.958 & $\begin{array}{c}- \\
19.248\end{array}$ & 34 & .000 \\
\hline
\end{tabular}

Table 22 shows that Probability Value is lower than alpha $(\alpha)(0.000<0.05)$ and degree of freedom 94 which means that there is significant difference in post-survey. It indicated that the null hypothesis (H1) was accepted and, of course, the alternative hypothesis (H0) was rejected. It showed that the use of Show and Tell technique as an authentic material significantly improve the students' speaking and give significantly greater contribution to the students' speaking skill.

Based on research findings. The data analysis above shows that applying Show and Tell techniques is effective in improving students' speaking skills. In the post-survey, it can be seen in the table before after giving continuous treatment using show and tell technique.

\section{DISCUSSIONS}

In this section, researchers take 3 students as representations that have different abilities, namely students S8, S9, and S24. From these three students, there are differences in the comparison of speaking skills in Show and Tell technique, namely high, medium and low in the class. The first student is the student (S9), the study found that students could explain the topic in the pre-survey, because he is fluent and comprehensive in explaining the topic. In addition, after researchers provide treatment about Show and Tell technique, students are increasingly eager to put out the words 
spoken. Before the researcher gave treatment, he got a score of 9 in the pre-survey and after giving treatment, students got 16 scores in the post-survey.

The second student is a student (R24) got a moderate ability to describe a topic. After research provides treatment about Show and Tell technique, these students have the motivation to learn to speak, especially in terms of confidence to appear in public. After that, before the researcher gave treatment, she got a score 6 of pre-survey and after giving treatment the student got 13 scores on the post-survey. The third student is a student (R8). This student has a different comparison between the two students above, because he has a very low level of student R9 and student R24. After the researcher gives treatment about Show and Tell students are lazy to put out words and are ashamed to appear in front. Before the researcher gave treatment, he got 3 scores on the pre-survey and after giving the treatment, students got 9 scores on the post-survey.

The difference between Wulandari, in her thesis entitled "Meningkatkan rasa percaya diri anak usia dini melalui metode Show and Tell". The result of her research indicates the self-confidence of the students in group A PAUD Miana V increased after implementing the Show and Tell method.

The second research is Nurvitasyari, in her thesis entitled "The Use of Show and Tell (S\&T) method in Teaching Vocabulary at the Second year Students of Junior High School (SMP) Negeri 4 Galesong Selatan Kabupaten Takalar". The differences between research Nurvitasyari uses Show and Tell. Similarities between research Nurvitasyari teaching students' vocabulary.

The third study was Eka Trislijayanti (2015) had research "Penggunaan Metode Show and Tell Dalam Pembelajaran Bahasa Indonesia Untuk Meningkatkan Keterampilan Berbicara Siswa Kelas VII.C di SMP Negeri 1 Seririt Tahun Ajaran 2014/2015". The difference between Eka Trislijayanti concluded that an increase in the average score of students' speaking skills by applying the Show and Tell method with picture media occurred in cycle I and cycle II in CAR (Classroom Action Research).

Based on the explanation, speaking teaching skills using Show and Tell technique at SMA Negeri 2 Palopo, the students got a significant improvement in their speaking skills scores. Therefore, it can be stated that Show and Tell technique in teaching speaking learning have solved students' speaking skills for Eleventh grade students of SMA Negeri 2 Palopo. So, the hypothesis put forward in this study that says "the effective Show and Tell technique to teach speaking skills" is accepted.

\section{CONCLUSIONS}

Based on the research findings it can be concluded that the use of Show and Tell technique is effective to improve students' speaking skill at Eleventh grade of SMA Negeri 2 Palopo. In other words, it can be proven that there are significant differences in the learning outcomes of students who learn to speak through Show and Tell technique with students who take learning without Show and Tell technique. Based on data analysis in the class, the pre-survey average score is 5.8900. While in the post-survey average score is 18.4300. Based on the analysis of the data it can be concluded that the teaching skills of speaking using effective Show and Tell technique at Eleventh grade of SMA Negeri 2 Palopo. It can be proven that the scores of students in the post-survey are higher than in the pre-survey.

\section{SUGGESTIONS}


Based on conclusion of study, the author suggests to attending parties:

1. For teachers, it is recommended to other teachers to use Show and Tell technique in teaching speaking as an effective way to improve students' speaking skills.

2. For students, they can use Show and Tell technique to improve their speaking skills

3. For researchers, in this thesis researchers hope that results of this study can be useful for readers. It is hoped that readers will get more information about the use of Show and Tell technique. In this study, future researchers are expected to conduct research to find other significance of Show and Tell technique in other English skills.

\section{BIBLIOGRAPGHY}

Ag. Bambang Setiyadi, Teaching English as Foreign Language, Jakarta: Terpadu 2006

Anonym, http://www.buzzle.com/articles/oral-communication-skills.html, accessed on January $16^{\text {th }} 2014$ at 10.42 am.

Artono Wadirma, et Al, English in Focus: For Grade VII Junior High School (SMP/MTS), (Jakarta: Pusat Perbukuan, DEPDIKNAS, 2008)

Anwar, L., Furwana, D., \& Iksan, M. (2020). Developing Reading Worksheet for Tenth Grade Students of SMA Negeri 4 Palopo. FOSTER: Journal of English Language Teaching, 1(1), 1-8. https://doi.org/10.24256/foster-jelt.v1i1.2

Christine C. M. Goh, Teaching Speaking in the Language Classroom, RELC Porthfolio series 15

Daryanto, Evaluasi Pendidikan (Jakarta PT. Rineka Cipta, 2007)

Djalius Syah, International English Conversation

Eka Ningsih, Improving Speaking Skill by Using Classroom Observation Technique at the Eight Year in SMP PMDS Putra Palopo, (Palopo: STAIN Palopo, 2013, )

Eka Trislijayanti, Penggunaan Metode Show And Tell Dalam Pembelajaran Bahasa Indonesia Untuk Meningkatkan Keterampilan Berbicara Siswa Kelas VII.C di SMP Negeri 1 Seririt Tahun Ajaran 2014/2015

Foley J. A., New Dimension in the Teaching of Oral Communication, (Singapore: SEAMEO, Regional Language Centre, 2005)

H. Dougles Brown, Teaching by Principles: An Interactive Approach to Language Pedagogy. (Ed II; San Fransisco: Addison Wesley Longman Inc., 2001), p. 268

H. Martin Manser, Oxford Learners Pocket Dictionary, (New Edition ; 1995)

Hebert H. Clark, Psychology and Language. (United State of America: Harcoun Brace Joranovicz, ich., 1997)

Hebert H. Clark and Eve V Clark, Psychology and Language, (United State of America: Harcount Brace Joranovich, ich., 1997), p. 223

Iksan, M. (2017). EMPOWERING BUSINESS GROUP PEANUT TENTENG. Proceeding International Conference on Natural and Social Science (ICONSS) 2017, 1(1). 
Irvy, I. I. (2020). Understanding the Learning Models Design for Indonesian Teacher. International Journal of Asian Education, 1(2), 95-106. https://doi.org/10.46966/ijae.v1i2.40

Imelda Wardi, Haan Basri, Abdul Waris, Improving The Ability in Writing Descriptive Text Trought Guided Question Technique, Jurnal of English Language Teaching Society (ELTS) Vol. 2, No 1, 2014

J.B Heaton, Writing English Language Test (Ed. I: New York Inc, 1998)

Jack C. Richards, Teaching Listening and Speaking from Theory to Practice (New York: Cambridge University Press, 2008)

Jack C. Richard and Willy A. Renandya, Methodology In Language Teaching (Ed. I: New York Cambridge University Press, 2002)

Leni Widia, I Nengah Astawa, Improving Speaking Skill Through Task Based Learning Strategy (Jurnal Santiaji Pendidikan, Vol. 4 , Nomor I, at Seventh Grade Students of SMP Negeri 3 Baturiti in Academy year 2014)

M. Basri Wello and Hafsah Amin J. Nur, An Introduction to ESP. (Ujung Pandang: Sunu Baraya, 1999)

Muhammad Rasyid and Hafsah Amin J. Nur, Teaching English and Foreign Language

Nasikhatun Listya Atika Farah, Improving the Student's English Speaking Skills Through Show and Tell method, (Universitas Madura: Madura 2016)

Nurvitasyari, The Use of Show and Tell (S\&T) Method in Teaching Vocabulary at the Second Year Students of Junior High School (SMP) Negeri 4 Galesong Selatan Kabupaten Takalar, 2017

Penny Ur, A., Course in Learning Teaching, Practice and Theory, (Great Britain: Cambridge University Press, 1996)

Siti Nurbaya, dkk, Improving Students Speaking Ability Through Role Play, (Tanjung Pura University: Pontianak 2015)

Siti Sadatul Fajriah, the Effect of Mind Mapping Technique on Students' Writing of Descriptive Text, A Thesis, (Jakarta: Syarif Hidayatullah State Islamic University 2017)

Sugiyono, Metode Penelitian Pendidikan: Pendekatan Kuantitatif, Kualitatif, Dan R\&D (Bandung:Alfabeta) P. 2015

Wilga M. Rivers, Teaching Foreign Language Skill, (Ed. II. London: The University of Chicago Press, 1981)

Willy A Renandya and Jack C Richards, Teaching Speakingin the Language Classroom, RELC portopolio series

Wulandari, Indarti A, Meningkatkan rasa percaya diri anak usia dini melalui metode Show and Tell, Subdistrict Sukasari, Bandung City School Year 2014/2015 